\title{
SDHAF2 Gene Mutation
}

National Cancer Institute

\section{Source}

National Cancer Institute. SDHAF2 Gene Mutation. NCI Thesaurus. Code C157451.

A change in the nucleotide sequence of the SDHAF2 gene. 